\title{
Distribution of Meloidogyne species in carrot in Brazil
}

\author{
Tiago Garcia da Cunha ${ }^{1}$ (i) Liliane Evangelista Visôtto ${ }^{1}$ (i) Letícia Mendes Pinheiro ${ }^{1}$ (i) \\ Pedro Ivo Vieira Good God ${ }^{1}$ (i) Juliana Magrinelli Osório Rosa ${ }^{2}$ (i) \\ Cláudio Marcelo Gonçalves Oliveira ${ }^{2}$ (i) Everaldo Antônio Lopes $^{1^{*} \text { (D) }}$
}

${ }^{1}$ Universidade Federal de Viçosa (UFV), Campus Rio Paranaíba, 38810-000, Rio Paranaíba, MG, Brasil. E-mail: everaldolopes@ufv.br. ${ }^{*}$ Corresponding author.

${ }^{2}$ Instituto Biológico, Campinas, SP, Brasil.

ABSTRACT: Root-knot nematodes (RKN-Meloidogyne spp.) are one of the most serious threats to carrot production worldwide. In Brazil, carrots are grown throughout the year, and economic losses due to RKN are reported. Since little is known on the distribution of RKN species in carrot fields in Brazil, we collected plant and soil samples from 35 fields across six states. Based on the morphology of perineal patterns, esterase phenotypes and species-specific PCR, three Meloidogyne species were identified: 60\% of the fields were infested with Meloidogyne incognita, M. javanica was reported in $42.9 \%$ of the areas, whereas M. hapla was detected in $17.1 \%$ of carrot fields. Mixed populations were reported in $20 \%$ of the areas with a predominance of $M$. incognita $+M$. javanica. The combination of morphological, biochemical, and molecular techniques is a useful approach to identify RKN species.

Key words: Daucus carota, integrative taxonomy, isozyme phenotypes, species-specific PCR.

Distribuição de espécies de Meloidogyne em cenoura no Brasil

RESUMO: Os nematoides-das-galhas (RKN - Meloidogyne spp.) são uma das mais sérias ameaças à produção de cenoura no mundo. No Brasil, as cenouras são cultivadas ao longo do ano, e as perdas econômicas devido à RKN são frequentemente relatadas. Como pouco se sabe sobre a distribuição de espécies RKN em campos de cenoura no Brasil, coletamos amostras de plantas e solo de 35 campos em seis estados. Baseado na morfologia do padrão perineal, fenótipos de esterase elou PCR espécie-específica, três espécies de Meloidogyne foram identificadas: $60 \%$ dos campos estavam infestados por Meloidogyne incognita, M. javanica foi encontrada em 42,9\% das áreas, enquanto M. hapla foi detectada em 17,1\% dos campos de cenoura. Populações mistas foram encontradas em $20 \%$ das áreas, com predominância de M. incognita + M. javanica. A combinação de técnicas morfológicas, bioquímicas e moleculares é uma abordagem útil para identificar espécies de RKN.

Palavras-chave: Daucus carota, taxonomia integrativa, fenótipos de isoenzimas, PCR espécie-especifica.

\section{INTRODUCTION}

Plant-parasitic nematodes are one of the main biotic causes of carrot (Daucus carota L.) crop losses worldwide (WALKER, 2004). This crop can be parasitized by more than ninety species of nematodes, belonging to the genera Pratylenchus Filipjev, Longidorus (Micoletzky) Filipjev, Paratylenchus Micoletzky, Belonolaimus Steiner, Paratrichodorus Siddiqi, Rotylenchus Filipjev, Ditylenchus Filipjev, Hemicycliophora de Man and Meloidogyne Goeldi (WALKER, 2004; TEKLU et al., 2016).

Root-knot nematodes (Meloidogyne spp.) can induce galling, forking, stunting, and fasciculation of carrot roots. Ultimately, attack by root-knot nematodes can lead to quality losses of the taproot (WALKER, 2004; WESEMAEL et al., 2011; HEVE et al., 2015). Severity of symptoms depends on a combination of factors, such as soil texture, temperature, and water content, carrot cultivar, nematode species and its population density in soil (HEVE et al., 2015).

In Brazil, carrots are grown throughout the year under irrigation, in deep and medium-textured soils. Thus, soil conditions in the main areas of carrot cultivation in the country are conducive to root-knot nematodes (BONTEMPO et al., 2014). Furthermore, most of the carrot genotypes used in 
the country are susceptible to root-knot nematodes. The municipalities of Rio Paranaíba, São Gotardo, Carandaí, and Santa Juliana, Minas Gerais State and Cristalina, Goiás State are among the major producers of carrots in Brazil. In these places, carrots are eventually grown in nematode-infested fields, due to the limited availability of pathogen-free areas. Thus, information on the geographical distribution of Meloidogyne species can be critical for designing efficient control strategies, including crop rotation with non-host plants, the development of resistant cultivars and the application of chemical and biological nematicides (CUNHA et al., 2018; LOPES et al., 2018).

The major root-knot nematode species that cause losses in carrot worldwide are $M$. javanica (Treub) Chitwood, M. incognita (Kofoid \& White) Chitwood, M. hapla Chitwood, M. arenaria (Neal) Chiwood, M. fallax Karssen, M. chitwoodi Golden et al. (WESEMAEL et al., 2011; ONKENDI et al., 2014). In Brazil, little is known about the distribution of Meloidogyne species in carrot fields. It is assumed that M. fallax and M. chitwoodi are not present in Brazil (MAPA, 2018) and $M$. incognita and $M$. javanica are the most prevalent species in the country. To study the distribution of Meloidogyne species on the carrot in Brazil, we collected plant and soil samples from 35 fields across six states and identified the species using morphological, biochemical, and molecular techniques.

\section{MATERIALS AND METHODS}

The root-knot nematode populations were collected from various carrot fields across Brazil (Figure 1). Sampled sites were georeferenced using a GPS receiver (Garmin ${ }^{\circledR}$, Model Etrex H). In each field, we collected a composite sample with $1,500 \mathrm{~cm}^{3}$ of

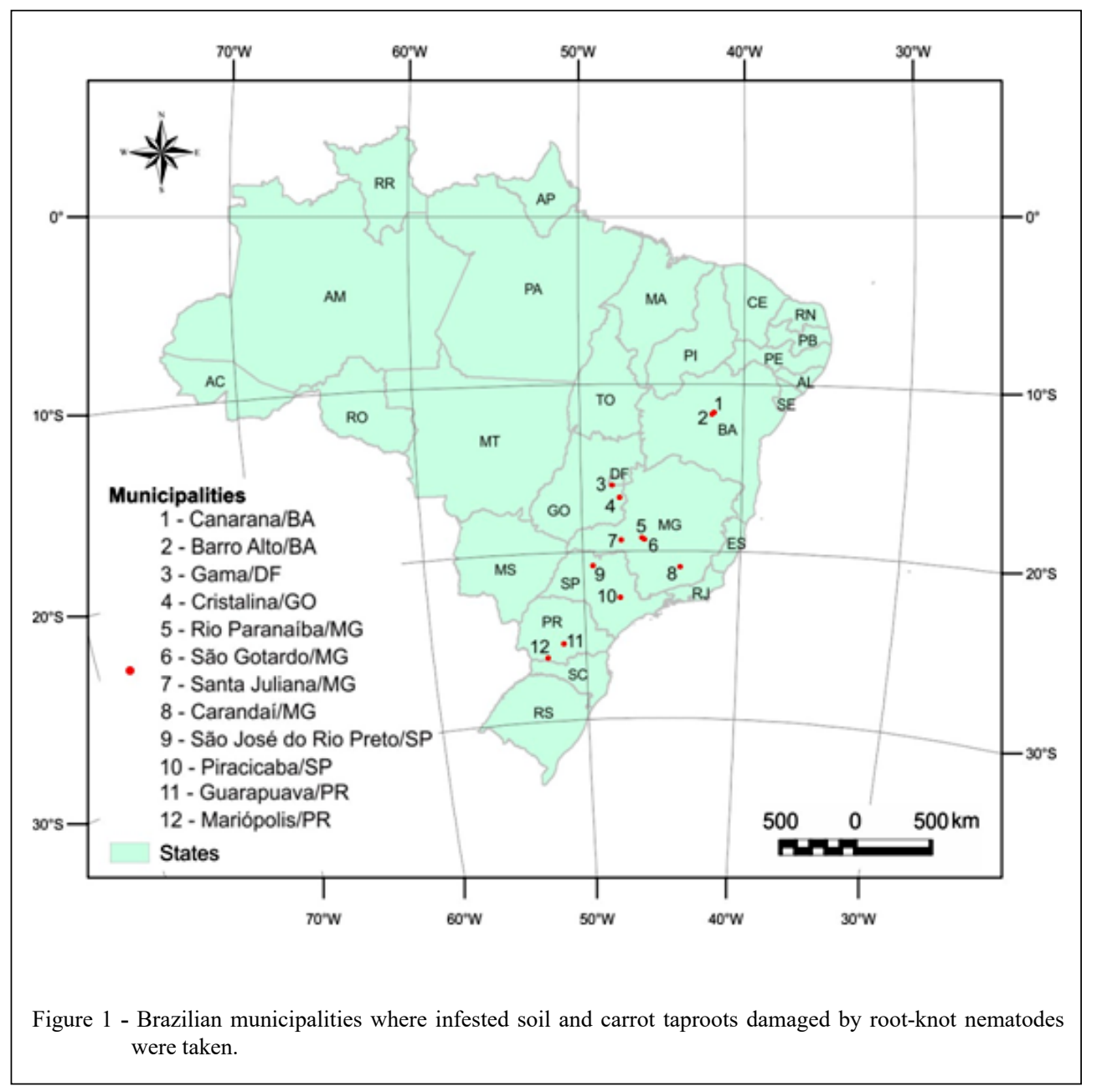

Ciência Rural, v.51, n.5, 2021. 
soil and 1 to $2 \mathrm{~kg}$ of roots with galls. Styrofoam boxes were used to provide temperature-buffering capacity during sample transportation to the laboratory.

Soil samples were homogenized, and we used $100 \mathrm{~cm}^{3}$ for nematode extraction by the centrifugal-flotation method (JENKINS, 1964). RKN females were extracted from the root samples for species identification. The remaining of the soil was stored in a refrigerator at $8{ }^{\circ} \mathrm{C}$ or used for growing tomato cv. Santa Cruz Kada in greenhouse $(26 \pm 2$ $\left.{ }^{\circ} \mathrm{C}\right)$ to maintain the population for further use.

\section{Identification of Meloidogyne species}

We identified Meloidogyne species by the integration of the morphological (perineal pattern), biochemical (esterase phenotypes) and molecular (species-specific PCR) techniques (CUNHA et al., 2018). For identification based on morphology, we randomly picked 10-20 mature RKN females from roots from each carrot field for analysis of perineal patterns under light microscopy (HARTMAN \& SASSER, 1985). Esterase activity of ten mature females from each field was analyzed according to the method of ESBENSHADE \& TRIANTAPHYLLOU (1990). For DNA extraction, we used the protocol reported by LOPES et al. (2018), with modifications. Fifteen second-stage juveniles or females were individually transferred to a microtube with $15 \mu$ of nuclease-free water, $3 \mu \mathrm{l}$ of $5 \mathrm{X}$ GoTaq ${ }^{\circledR}$ Flexi PCR buffer (Promega, USA), and five 1-mm glass beads (Thistle Scientific, UK). Nematodes were disrupted in a dental amalgamator (Dentomat ${ }^{\circledR}$, Model 600 BR, Degussa, Germany) for $30 \mathrm{sec}$ at $50 / 60 \mathrm{~Hz}$. Two microliters of proteinase $\mathrm{K}\left(100-\mathrm{mg} \mathrm{ml}^{-1}\right)$ were added to each microtube, followed by incubation for $60 \mathrm{~min}$ at $60{ }^{\circ} \mathrm{C}, 15 \mathrm{~min}$ at $95^{\circ} \mathrm{C}$ and $2 \mathrm{~min}$ at $15^{\circ} \mathrm{C}$. DNA was stored at $-20^{\circ} \mathrm{C}$ until use.

RKN species were identified using the molecular diagnostic key of ADAM et al. (2007) with modifications. For $M$. incognita, we used the primers MI2F4/MIR1 (KIEWNICK et al., 2013) due to the absence of amplification products using the primers MI-F/MI-R (MENG et al., 2004). We used the primers Fjav/Rjav (ZIJLSTRA et al., 2000) for $M$. javanica, JMV primers for $M$. hapla (WISHART et al., 2002), Far/Rar set for M. arenaria (ZIJLSTRA et al., 2000), and the universal primers 194/195 for the region 5S-18S rDNA (BLOK et al., 1997).

The amplification of DNA fragments was performed in a Veriti ${ }^{\circledR}$ Thermal Cycler (Applied Biosystems, USA) in a final volume of $12.5 \mu \mathrm{l}$ and using $2.5 \mu 1$ a $5 X$ GoTaq ${ }^{\circledR}$ Flexi PCR buffer (Promega), 1.25 $\mu \mathrm{l}$ of each dNTP at $2 \mathrm{mM}$ (Promega), $0.75 \mu \mathrm{l}$ of 25
$\mathrm{mM} \mathrm{MgCl}{ }_{2}$ (Promega), $0.5 \mu \mathrm{l}$ of each primer at $10 \mu \mathrm{M}$, $0.0625 \mu 1$ of GoTaq ${ }^{\circledR}$ Flexi (Promega), $1 \mu 1$ of DNA, and $6.43 \mu \mathrm{l}$ of nuclease-free water. All amplifications included positive controls for $M$. javanica or $M$. incognita, and a control without template DNA.

Except for $M$. incognita, amplifications were conducted using cycling conditions of $94^{\circ} \mathrm{C}$ for $2 \mathrm{~min}$, followed by 45 cycles of $94{ }^{\circ} \mathrm{C}$ for $30 \mathrm{sec}$, with specific annealing conditions for each primer set $\left(50{ }^{\circ} \mathrm{C} / 30 \mathrm{sec}\right.$ for $194 / 195$ and JMV primers; 61 ${ }^{\circ} \mathrm{C} / 30$ sec for Far/Rar; $64{ }^{\circ} \mathrm{C} / 30 \mathrm{sec}$ for Fjav/Rjav), $72{ }^{\circ} \mathrm{C}$ for $90 \mathrm{sec}(194 / 195$ and JMV primers) or 60 sec (Fjav/Rjav and Far/Rar), with a final cycle of 72 ${ }^{\circ} \mathrm{C}$ for $7 \mathrm{~min}$. For M. incognita using MI2F4/MIR1 primers, thermal cycling conditions were of initial denaturation at $95{ }^{\circ} \mathrm{C}$ for $15 \mathrm{~min}$, followed by 40 cycles of denaturation at $95{ }^{\circ} \mathrm{C}$ for $40 \mathrm{sec}$, annealing at $64{ }^{\circ} \mathrm{C}$ for $60 \mathrm{sec}$ and extension at $72{ }^{\circ} \mathrm{C}$ for $60 \mathrm{sec}$, with a final extension of $72{ }^{\circ} \mathrm{C}$ for $7 \mathrm{~min}$ PCR products were separated by $1.14 \%$ agarose gel electrophoresis at $45 \mathrm{~V}$ for $90 \mathrm{~min}$ using $1 \mathrm{X}$ TBE buffer. Gels were stained with $0.7 \mu \mathrm{l}$ of SYBR Safe $(10.000 \mathrm{x}$, Invitrogen, Carlsbad, USA) and visualized under UV illumination and photographed.

\section{RESULTS AND DISCUSSION}

Meloidogyne incognita, M. javanica, and M. hapla were the species reported in 35 carrot fields in six Brazilian states (Table 1, Figure 2). Sixty percent of the carrot fields were infested with $M$. incognita. The second most prevalent species was M. javanica, which was found in $42.9 \%$ of the areas, alone or in a mixed population with M. hapla or $M$. incognita. Meloidogyne hapla was detected in 17.1\% of the areas, all located in São Gotardo - MG. Mixed populations of Meloidogyne were detected in $20 \%$ of the fields, with a predominance of $M$. incognita + $M$. javanica. We found the mixture of $M$. incognita and $M$. javanica in all fields from Gama - DF and Carandaí - MG (Table 1).

The perineal patterns of the females were consistent with that expected for $M$. incognita, $M$. javanica and $M$. hapla. The esterase (EST) phenotype $\mathrm{J} 2(\mathrm{Rm}=1.0 ; 1.25)$ was observed in the populations RIO 04 and RIO 11 of M. javanica (Table 1). All other populations of this species showed the EST-phenotype $\mathrm{J} 3(\mathrm{Rm}=1.0 ; 1.25 ; 1.4)$. EST-phenotype H1 $(\mathrm{Rm}=$ 1.1) was detected in all M. hapla populations. The phenotype I1 $(\mathrm{Rm}=1.0)$ was detected in all $M$. incognita populations, except for RIO 16, which showed two isoforms: one strong band at $\mathrm{Rm}=1.0$ and a weak band at $\mathrm{Rm}=1.05$ (Figure 3 ).

Ciência Rural, v.51, n.5, 2021. 
Table 1 - Distribution of Meloidogyne species in 35 carrot production fields in Brazil.

\begin{tabular}{|c|c|c|}
\hline Municipality (State) & Field & Species \\
\hline Barro Alto (BA) & $\mathrm{N} 02$ & M. incognita ${ }^{l, 3}$ \\
\hline Canarana (BA) & N 01 & M. incognita ${ }^{1,3}$ \\
\hline Carandaí (MG) & CAD 01 & M. incognita $^{1,2}+M$. javanica $^{3}$ \\
\hline Carandaí (MG) & CAD 02 & M. incognita ${ }^{l, 2}+M$. javanica ${ }^{l, 3}$ \\
\hline Carandaí (MG) & CAD 09 & M. incognita ${ }^{1,2}+M$. javanica ${ }^{2,3}$ \\
\hline Carandaí (MG) & CAD 10 & M. incognita ${ }^{1,2,3}+$ M. javanica ${ }^{2}$ \\
\hline Cristalina (GO) & $\mathrm{CO} 03$ & M. javanica ${ }^{l, 3}$ \\
\hline Cristalina (GO) & $\mathrm{CO} 04$ & M. javanica ${ }^{l, 3}$ \\
\hline Gama (DF) & $\mathrm{CO} 01$ & M. incognita ${ }^{1,3}+M$. javanica ${ }^{1,3}$ \\
\hline Gama (DF) & $\mathrm{CO} 02$ & M. incognita ${ }^{1,3}+M$. javanica ${ }^{1,3}$ \\
\hline Guarapuava (PR) & S 02 & M. javanica ${ }^{l, 3}$ \\
\hline Mariópolis (PR) & S 01 & M. incognita ${ }^{l, 3}$ \\
\hline Piracicaba (SP) & SP 02 & M. incognita ${ }^{l, 2}$ \\
\hline Rio Paranaíba (MG) & RIO 03 & M. incognita in $^{1,2,3}$ \\
\hline Rio Paranaíba (MG) & RIO 04 & M. javanica ${ }^{1,2,3}$ \\
\hline Rio Paranaíba (MG) & RIO 05 & M. incognita i, $2,3^{1}$ \\
\hline Rio Paranaíba (MG) & RIO 06 & M. javanica ${ }^{1,2,3}$ \\
\hline Rio Paranaíba (MG) & RIO 09 & M. incognita ${ }^{1,2,3}$ \\
\hline Rio Paranaíba (MG) & RIO 10 & M. javanica ${ }^{1,2,3}$ \\
\hline Rio Paranaíba (MG) & RIO 11 & M. javanica ${ }^{1,2,3}$ \\
\hline Rio Paranaíba (MG) & RIO 16 & M. incognita ${ }^{1,2,3}$ \\
\hline Santa Juliana (MG) & TRI 06 & M. incognita in $^{1,3}$ \\
\hline Santa Juliana (MG) & TRI 07 & M. incognita ${ }^{1,2,3}$ \\
\hline Santa Juliana (MG) & TRI 08 & M. incognita in $^{1,3}$ \\
\hline São Gotardo (MG) & SG 01 & M. incognita ${ }^{1,2}$ \\
\hline São Gotardo (MG) & SG 02 & M. incognita ${ }^{1,2}$ \\
\hline São Gotardo (MG) & SG 03 & M. javanica ${ }^{1,2,3}+$ M. hapla ${ }^{1,2}$ \\
\hline São Gotardo (MG) & SG 04 & M. javanica ${ }^{1,2,3}$ \\
\hline São Gotardo (MG) & SG 05 & M. hapla ${ }^{1,2}$ \\
\hline São Gotardo (MG) & SG 06 & M. hapla ${ }^{1,2}$ \\
\hline São Gotardo (MG) & SG 07 & M. hapla ${ }^{1,2}$ \\
\hline São Gotardo (MG) & SG 08 & M. hapla ${ }^{1,2}$ \\
\hline São Gotardo (MG) & SG 09 & M. hapla ${ }^{l, 2}$ \\
\hline São Gotardo (MG) & SG 10 & M. incognita ${ }^{l, 2,3}$ \\
\hline São José do Rio Pardo (SP) & SP 01 & M. incognita in $^{l, 2}$ \\
\hline
\end{tabular}

Brazilian states: MG - Minas Gerais; SP - São Paulo; GO - Goiás; PR - Paraná; BA - Bahia; DF - Distrito Federal. ${ }^{1}$ Identification based on perineal pattern of females; ${ }^{2}$ Identification based on esterase phenotypes; ${ }^{3}$ Identification based on polymerase chain reaction.

Meloidogyne javanica and M. hapla were identified by PCR using the primers Fjav/ Rjav and JMV, with amplicons of $720 \mathrm{bp}$ and 440 bp, respectively (Figure 3 ). The use of the primers MIF/MIR, recommended on the molecular key proposed by ADAM et al. (2007), did not result in the amplification of $999 \mathrm{bp}$ fragments in populations previously identified as $M$. incognita by esterase phenotypes and perineal patterns. Amplicons were not observed even when pure populations of $M$. incognita were used as positive controls. However, typical amplicons of $300 \mathrm{bp}$ were observed for $M$. incognita when the primers MI2F4/MIR1 were used.

In our survey, we reported $M$. incognita, $M$. javanica, and $M$. hapla in carrot crops in Brazil, with the occurrence of $M$. incognita and $M$. javanica in more than $85 \%$ of the production fields. These species have been reported to cause damage to vegetable crops in Brazil, including carrots (CARNEIRO et al., 2008; ROSA et al., 2013; SILVA et al., 2016). Meloidogyne incognita and $M$. javanica have various hosts, especially among vegetable crops, which 


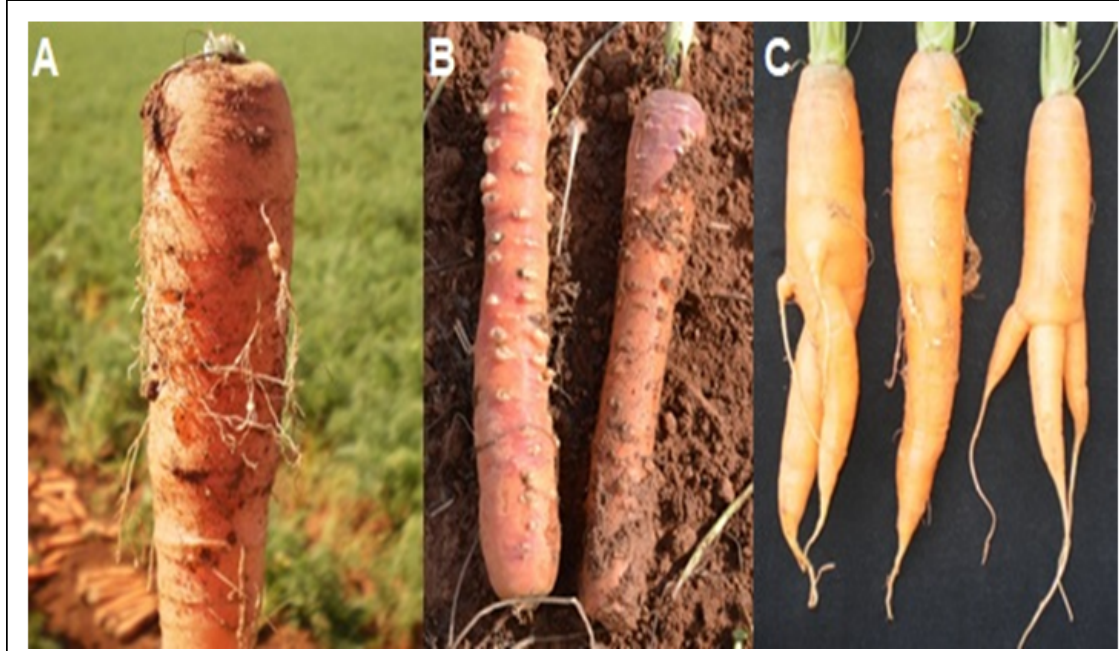

Figure 2 - Carrot roots damaged by Meloidogyne species in Brazil. A - Galls on the secondary roots (M. incognita, Population TRI 06, Santa Juliana - Minas Gerais state). B Severe galling near the lenticels of the taproot (M. incognita, Population RIO 16, Rio Paranaíba, Minas Gerais state). C - Forked taproots (M. javanica, Population CO 04, Cristalina, Goiás state).

facilitate their establishment and survival in the field. As a result, crop rotation including commercial crops is limited, with few options remaining, which include cover crops and green manures, including Brachiaria decumbens Stapf and B. ruziziensis Germain et Evrard, pearlmillet [Pennisetum glaucum (L). R. Br], crotalaria (Crotalaria spectabilis Roth), sunn hemp (Crotalaria juncea L.), and velvet bean [Mucuna pruriens (L). DC.] (LOPES et al., 2019). The occurrence of mixed populations of $M$. incognita and $M$. javanica, as we reported here makes management even more difficult. In this study, other tropical root-knot nematodes, such as $M$. arenaria and $M$. enterolobii Yang \& Eisenback, were not detected in carrot fields; although, they have been reported in areas of vegetable production in Brazil (ROSA et al., 2013; SILVA et al., 2016).

In the cooler regions, $M$. hapla causes economic losses in carrot (GUGINO et al., 2006). The neighboring municipalities of São Gotardo and Rio Paranaíba stand out as one of the largest areas of carrot production in Brazil with productivity above the national average (HORTIFRUTI, 2019). As they are located above the 1000-m altitude, the temperature in these places is mild, which favored the establishment of $M$. hapla, which may cause losses mainly in the cooler periods of the year.

In 2009, the species M. polycephannulata CHARCHAR et al. (2009), the carrot root-knot nematode, was described from a population reported in a carrot field in Rio Paranaíba (CHARCHAR et al., 2009). We collected samples in the same farm where the type population was reported and concluded that the population RIO 16 had similarities to those described for M. polycephannulata, especially the esterase phenotype I2. However, recently MONTEIRO et al. (2019) have shown that $M$. polycephannulata is $\mathrm{t}$ a junior synonym of $M$. incognita, based on morphological and morphometric characters, and biochemical, molecular, and phylogenetic studies. For this reason, in agreement with MONTEIRO et al. (2019), we classified the population RIO 16 as M. incognita.

The use of integrative taxonomy is an approach that should be used for accurate identification of root-knot nematode populations (OLIVEIRA et al., 2011; CUNHA et al., 2018). The observation of female perineal patterns is simple, it is relatively reliable for the identification of species such as M. javanica, but it may not be accurate enough to separate several species of Meloidogyne, including M. incognita, $M$. enterolobii, and $M$. inornata Lordello (CUNHA et al., 2018). The analysis of esterase phenotypes is commonly used in routine laboratories in Brazil as a diagnosis technique for root-knot nematodes. However, molecular-based diagnostics have become more popular recently, due to the number of protocols available in the literature and reduction in the cost of 


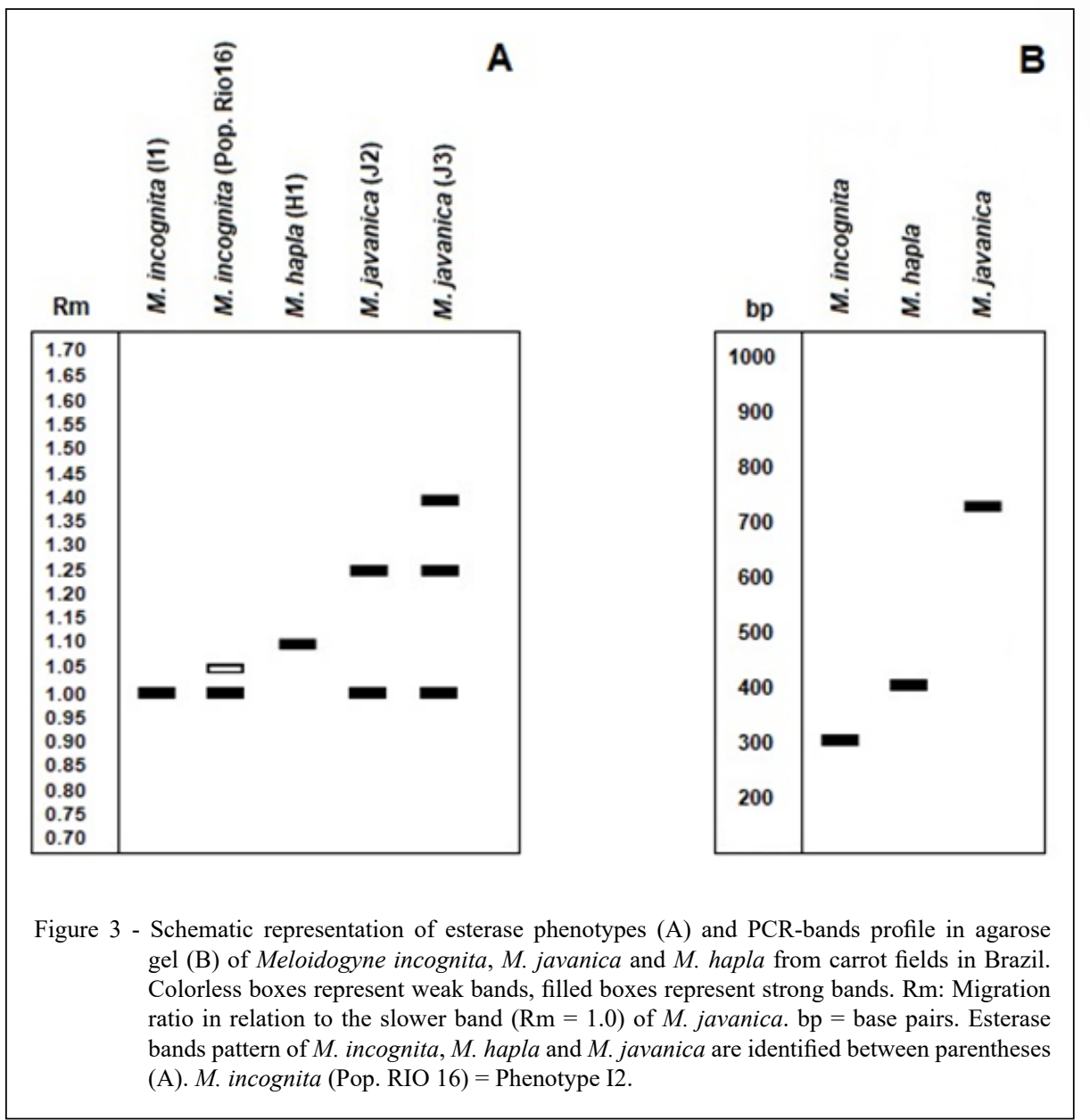

equipment and consumables. Eggs, juveniles, and adults can be used as the DNA source, which is an advantage of the molecular methods compared to perineal patterns and isoenzyme phenotypes that require mature females (OLIVEIRA et al., 2011).

The use of various diagnostic techniques may improve the accuracy of diagnostics and increase the chance of detecting mixed populations, since more nematodes will be used. Considering the 01-population with CAD as an example, a maximum of 30 females were used for identification based on perineal pattern of females and esterase phenotypes. If only these individuals were evaluated, we would conclude that only $M$. incognita was infecting carrots in that specific field. When 15 additional specimens were used in the molecular assay, M. javanica was detected. This was not due to a previous failure of diagnosis since the perineal and esterase patterns of $M$. incognita and $M$. javanica are distinct, but simply because the number of nematodes assessed was higher and by chance, we used individuals of $M$. javanica for molecular analysis.

The DNA extraction method used in this research is simple and produces enough material for identification by species-specific PCR. The molecular identification protocol proposed by ADAM et al. (2007) proved to be efficient, except for failing to identify $M$. incognita populations using MIF/ MIR primers (MENG et al., 2004). KIEWNICK et al. (2013) also reported a failure in the molecular diagnosis of $M$. incognita using this same set of primers. Based on the $M$. incognita-specific amplicons of 399 bp using primers inc-K14-F / inc-K14-R (RANDIG et al., 2002), KIEWNICK et al. (2013) designed primers MI2F4/MIR1, which amplify a 300 bp fragment and can be used in a multiplex reaction to identify $M$. incognita, $M$. javanica, and $M$. arenaria. The populations of $M$. incognita in carrots from this study may be genetically similar to the Brazilian populations of $M$. incognita that were used to design

Ciência Rural, v.51, n.5, 2021. 
the SCAR primers inc-K14-F / inc-K14-R, and the starting point for designing the primers MI2F4/MIR1.

Information on the occurrence and distribution of root-knot nematodes in carrots can be used for designing integrated management systems adapted to local root-knot nematode problems (WESEMAEL et al., 2011). Carrot breeding programs and producers of chemical and biological nematicides may benefit from our findings by targeting the most prevalent RKN species.

\section{CONCLUSION}

Meloidogyne incognita, M. javanica, and M. hapla infect carrots in six Brazilian states, with a prevalence of $M$. incognita and $M$. javanica, and the occurrence of mixed populations in some fields. Meloidogyne hapla is reported in São Gotardo $\mathrm{MG}$, where temperatures are mild year-round. The combination of morphological, biochemical, and molecular techniques is a useful approach to identify RKN species.

\section{ACKNOWLEDGEMENTS}

This study was supported by the Fundação de Amparo à Pesquisa do Estado de Minas Gerais (FAPEMIG). E.A. Lopes thanks Conselho Nacional de Desenvolvimento Científico e Tecnológico (CNPq) (Research Productivity Grant 306267/20187. The authors thank Dr. Rosangela Dallemole-Giaretta and Dr. Valdir Lourenço Júnior for sending samples and Dr. Reynaldo F. Faria Filho for preparing the map.

\section{DECLARATION OF CONFLICT OF} INTERESTS

The authors declare no conflict of interest. The founding sponsors had no role in the design of the study; in the collection, analysis, or interpretation of data; in the writing of the manuscript, and in the decision to publish the results.

\section{AUTHORS' CONTRIBUTIONS}

All authors contributed equally for the conception and writing of the manuscript. All authors critically revised the manuscript and approved of the final version.

\section{REFERENCES}

ADAM, M. A. M. et al. Molecular diagnostic key for identification of single juveniles of seven common and economically important species of root-knot nematode (Meloidogyne spp.). Plant Pathology, v.56, p.190-197, 2007. Available from: <https:dx.doi org/10.1111/j.1365-3059.2006.01455.x> Accessed: Jun. 08, 2020. doi: $10.1111 / \mathrm{j} .1365-3059.2006 .01455 . \mathrm{x}$

BLOK, V. C. et al. Comparison of sequences from the ribosomal DNA intergenic region of Meloidogyne mayaguensis and other major tropical root knot nematodes. Journal of Nematology, v.29, p.16-22, 1997.

BONTEMPO, A. F. et al. Pochonia chlamydosporia controls Meloidogyne incognita on carrot. Australasian Plant Pathology, v.43, p.421-424, 2014. Available from: <https:dx.doi.org/10.1007/s13313-014-0283-x>. Accessed: Jun. 08, 2020. doi: 10.1007/s13313-014-0283-x.

CARNEIRO, R. M. D. G. et al. Ocorrência de Meloidogyne spp. e fungos nematófagos em hortaliças no Distrito Federal, Brasil. Nematologia Brasileira, v.32, p.135-141, 2008.

CHARCHAR, J. M. et al. Meloidogyne polycephannulata $\mathrm{n}$. sp. (Nematoda: Meloidogynidae), a root-knot nematode parasitizing carrot in Brazil. Journal of Nematology, v.41, p.174-186, 2009.

CUNHA, T. G. et al. Diagnostic methods for identification of root-knot nematodes species from Brazil. Ciência Rural, v.48, e20170449, 2018. Available from: $<$ https:dx.doi.org/10.1590/01038478cr20170449>. Accessed: Jun. 08, 2020. doi: 10.1590/0103$8478 \mathrm{cr} 20170449$.

ESBENSHADE, P. R.; TRIANTAPHYLLOU, A. C. Isozyme phenotypes for the identifications of Meloidogyne species. Journal of Nematology, v.22, p.10-15, 1990.

GUGINO, B. K. et al. Damage and management of Meloidogyne hapla using oxamyl on carrot in New York. Journal of Nematology, v.38, p.483-490, 2006.

HARTMAN, R. M.; SASSER, J. N. Identification of Meloidogyne species on the basis of differential host test and perineal pattern morphology. In: BARKER, K.R., CARTER, C.C. \& SASSER, J.N. (Eds) An advanced treatise on Meloidogyne, Vol. 2. Methodology. Raleigh: North Carolina State University Graphics, p.69-77, 1985.

HEVE, W. K. et al. Damage thresholds and population dynamics of Meloidogyne chitwoodi on carrot (Daucus carota) at different seed densities. Nematology, v.17, p.501-514, 2015. Available from: $<$ https:dx.doi.org/10.1163/15685411-00002884> Accessed: Jun. 08, 2020. doi: 10.1163/15685411-00002884.

HORTIFRUTI BRASIL. Anuário 2019-2020. Available from: $<$ https://www.hfbrasil.org.br/br/revista/acessar/completo/anuario-2019-2020-retrospectiva-2019-perspectivas-2020-dos-hf-s. aspx>. Accessed: Sep. 29, 2020.

JENKINS, W. R. A rapid centrifugal-flotation technique for separating nematodes from soil. Plant Disease Reporter, v.48, p.692, 1964.

KIEWNICK, S. et al. Identification of the tropical root-knot nematode species Meloidogyne incognita, M. javanica and M. arenaria using a multiplex PCR assay. Nematology, v.15, p.891-894, 2013. Available from: <https:dx.doi.org/10.1163/15685411-00002751>. Accessed: Jun. 08, 2020. doi: 10.1163/15685411-00002751.

LOPES, E. A. et al. Eco-friendly approaches to the management of plant-parasitic nematodes. In: ANSARI, R.; MAHMOOD, I. (Eds) Plant health under biotic stress. Singapore, Springer, p. 167-186, 2019. Available from: <https:dx.doi.org/10.1007/978981-13-6043-5 9>. Accessed: Jun. 08, 2020. doi: 10.1007/978981-13-6043-5_9.

LOPES, E. A. et al. Does soil warming affect the interaction between Pasteuria penetrans and Meloidogyne javanica in tomato

Ciência Rural, v.51, n.5, 2021. 
plants? Plant Pathology, v.67, p.1777-1783, 2018. Available from: $<$ https:dx.doi.org/10.1111/ppa.12877>. Accessed: Jun. 08, 2020. doi: $0.1111 /$ ppa. 12877 .

MAPA - Ministério da Agricultura, Pecuária e Abastecimento Lists of quarantine pests present or absent in Brazil. 2018. Normative Instructions $\mathrm{N}^{\circ}{ }^{\circ}$ 39, October 1 . Available from: <https://www in.gov.br/materia/asset_publisher/Kujrw0TZC2Mb/content/ id/43460217/do1-2018-10-02-instrucao-normativa-n-39-de-1-deoutubro-de-2018-43460055>. Accessed: Apr. 5, 2020.

MENG, Q. P. et al. PCR assays for rapid and sensitive identification of three major root-knot nematodes, Meloidogyne incognita, $M$. javanica and $M$. arenaria. Acta Phytopathologica Sinica, v.34, p.204-210, 2004.

MONTEIRO, J. M. S. et al. Additional information on Meloidogyne polycephannulata and its proposal as a junior synonym of $M$. incognita. Nematology, v.21, p.129-146, 2019. Available from: $<$ https:dx.doi.org/10.1163/15685411-00003202>. Accessed: Jun. 08, 2020. doi: 10.1163/15685411-00003202.

OLIVEIRA, C. M. G. et al. Morphological and molecular diagnostics for plant parasitic nematodes: working together to get the identification done. Tropical Plant Pathology, v.36, p.65-73, 2011. Available from: <https:dx.doi.org/10.1590/S1982 56762011000200001>. Accessed: Jun. 08, 2020. doi: 10.1590 S1982-56762011000200001.

ONKENDI, E. M. et al. The threat of root-knot nematodes (Meloidogyne spp.) in Africa: a review. Plant Pathology, v.63, p.727-737, 2014. Available from: <https:dx.doi.org/10.1111/ ppa.12202>. Accessed: Jun. 08, 2020. doi: 10.1111/ppa.12202.

RANDIG, O. et al. Genetic diversity of root-knot nematodes from Brazil and development of SCAR markers specific for the coffeedamaging species. Genome, v.45, p.862-870, 2002. Available from: <https:dx.doi.org/10.1139/g02-054>. Accessed: Jun. 08, 2020. doi: $10.1139 / \mathrm{g} 02-054$
ROSA, J. M. O. et al. Nematoide das galhas em áreas de cultivo de olerícolas no estado de São Paulo. Nematologia Brasileira, v.37, p.15-19, 2013

SILVA, M. C. L. et al. Espécies de Meloidogyne associadas a vegetais em microrregiões do estado do Ceará. Revista Ciência Agronômica, v.47, p.710-719, 2016. Available from: $<\mathrm{https}: \mathrm{dx}$. doi.org/10.5935/1806-6690.20160085>. Accessed: Jun. 08, 2020. doi: 10.5935/1806-6690.20160085.

TEKLU, M. G. et al. Damage thresholds and population dynamics of Pratylenchus penetrans on carrot (Daucus carota L. cv. Nerac) at three different seed densities. European Journal of Plant Pathology, v.146, p.117-127, 2016. Available from: <https:dx.doi. org/10.1007/s10658-016-0898-6>. Accessed: Jun. 08, 2020. doi: $10.1007 / \mathrm{s} 10658-016-0898-6$

WALKER, G. E. Associations between carrot defects and nematodes in South Australia. Australasian Plant Pathology, v.33, p.579-584, 2004. Available from: $<$ https:dx.doi.org/10.1071/ AP04059>. Accessed: Jun. 08, 2020. doi: 10.1071/AP04059.

WESEMAEL, W. M. L. et al. Root-knot nematodes (Meloidogyne spp.) in Europe. Nematology, v.13, p.3-16, 2011. Available from: $<$ https:dx.doi.org/10.1163/138855410X526831>. Accessed: Jun. 08, 2020. doi: 10.1163/138855410X526831

WISHART, J. et al. Ribosomal intergenic spacer: a PCR diagnostic for Meloidogyne chitwoodi, M. fallax and M. hapla. Phytopathology, v.92, p.884-892, 2002. Available from: $<$ https:dx.doi.org/10.1094/PHYTO.2002.92.8.884>. Accessed: Jun. 08, 2020. doi: 10.1094/PHYTO.2002.92.8.884.

ZIJLSTRA, C. et al. M. Identification of Meloidogyne incognita, $M$. javanica and $M$. arenaria using sequence characterized amplified regions (SCAR) based PCR assays. Nematology, v.2, p.847-853, 2000. Available from: <https:dx.doi.org/10. 1163/156854100750112798>. Accessed: Jun. 08, 2020. doi: $10.1163 / 156854100750112798$. 